\title{
腎細胞癌に打ける手術療法の検討
}

\author{
第 1 報 腎摘除術について \\ 群馬大学泌尿器科学教室 (主任：山中英寿教授) \\ 小林幹男 田村芳美 岡村 桂吾 \\ 中田誠司 今井強一 山中 英寿
}

\section{CLINICAL STUDY OF OPERATIVE THERAPY FOR RENAL CELL CARCINOMA}

1. About Nephrectomy

\author{
Mikio Kobayashi, Yoshimi Tamura, Keigo Okamura, Seiji Nakata, \\ Kyoichi Imai and Hidetoshi Yamanaka \\ Department of Urology, Gunma University School of Medicine \\ (Director: Prof. H. Yamanaka)
}

A study was made on treatment-related factors, notably prognosis, in 148 patients treated by surgical resection of the primary lesion among 170 consecutive patients who were admitted to the Department of Urology, Gunma University for the treatment of renal cell carcinoma during the period from September 1961 through August 1989.

Operative procedures used in this series were radical nephrectomy in 100 patients, simple nephrectomy in 46, partial nephrectomy in 1 and tumor enucleation in 1 , lymph node dissection being performed in 53 of the 100 patients treated by radical nephrectomy.

The patients receiving surgical resection of the primary lesion were stratified according to sex, PS, disease stage, surgical procedure, lymph node dissection and weight of renal substance resected and comparisons were made on survival rate and recurrence rate among patients in different strata in an effort to observe if these factors are determinant of postoperative prognosis.

No significant difference in survival rate was observed between sexes. Patients displaying a PS value of 0 had a significantly higher survival rate than those having a PS value of 1 or above. Whereas a significant difference in survival rare was noted between stage $\mathrm{III}_{\mathrm{A}}+\mathrm{III}_{\mathrm{B}+\mathrm{C}}$ disease patients, no significant difference was observed among stage I, II and III patients, thus stages up to III $_{A}$ being considered low stage.

Radical nephrectomy was associated with a significantly higher survival rate than simple nephrectomy in low stage (stage I-II) disease patients. However, there was no significant difference in survival rate between stage I-II disease patients with vs. without lymph node dissection.

A significantly higher survival rate was obtained in patients having less than $500 \mathrm{~g}$ of renal substance removed than those having $500 \mathrm{~g}$ or more of renal substance removed. No significant difference was noted between the two groups of patients so far as those with stage $\mathrm{I}-\mathrm{III}_{\mathrm{A}}$ disease were concerned, however.

When the recurrence of malignancy was studied in relation to operative procedure and disease stage, it became obvious that the recurrence rate was lower in patients with stage I or II disease treated by radical nephrectomy than in those who underwent simple nephrectomy. Among patients treated by radical nephrectomy, those with stage II disease had recurrence rate (about 30\%) which was almost equal to that for those with stage $\mathrm{III}_{\mathrm{A}}$ disease.

Among stage III or more advanced disease patients, the extrapleural lumbar approach was employed for noncurative resection in all patients undergoing simple nephrectomy, while the transabdominal or thoracicoabdominal approach was used in patients treated by radical nephrectomy, allowing for an extensive operation involving retroperitoneal lymph node dissection, vena caval tumor 
thrombectomy or conjoined resection of contiguous organs.

Particularly in stage $\mathrm{III}_{\mathrm{A}}$ patients, since they had a survival rate not significantly different from that for stage I and II patients and a recurrence rate comparable to stage II patients, it was considered of utmost importance to perform a perfect tumor thrombectomy.

These results led us to conclude that a PS value of 0 is a primary prerequisite for a favorable outcome of surgery for renal cell carcinoma; that a radical nephrectomy is the treatment of choice for stage I-II disease, and that, for stage III or more advanced disease, an extended operation including radical nephrectomy by the thoracicoabdominal approach is highly recommendable, because it will certainly provide an improvement of prognosis.

Key words: renal cell carcinoma, radical nephrectomy, simple nephrectomy, lymphadenectomy

要旨：1961年 9 月から1989年 8 月までに群馬大学泌尿器科で入院治療した腎細胞癌170例のらち原発栄 摘除術が行われた148例に対して子後を中心に治療側因子の面から検討した.

手術術式は根治的腎摘除術 100 例, 単純腎摘除術 46 例, 腎部分摘除術 1 例おょび腎腫場核出術 1 例であ

り,リンパ節郭清は根治的腎摘除術が行われた100例中の53例に施行された。

手術に関して予後を観察する因子かどうかを性別, PS, stage, 腎摘除術式, リンパ節郭清の有無およ び腎摘出重量に分けて生存率の有意差検定を行い, また再発率についても検討を行った。

性別は男女間では特に有意差は認めなかった. PS では, PS が 0 と 1 以上の 2 群間での比較で前者が 有意に高い生存率であった。

stage 別では stage IIIA と IIIB+Cで有意差を認めたが， stage I，II，III では各々有意差を認めず， stage IIIA ‡でを low stage と考えた.

術式では単純腎摘除術と根治的腎摘除術を行った stage I II までの low stage 症例で, 後者が有意に 生存率は高かったが, リンパ節郭清の有用性について stage I〜II の症例で検討したところ特に有意差は 認めなかった。

腎摘出重量は $500 \mathrm{~g}$ 前後で比較したところ500 $\mathrm{g}$ 未満の症例で生存率は有意に高かったが, stage I 〜IIIA をでの検討では特に有意差を認めなかった.

再発に関して, 手術術式による各 stage 別検討で, 根治的腎摘除術が単純腎摘除術に比べ stage I, II ともに再発率は低く，かつ stage I が stage II に比べ再発率は低かった。 また，根治的腎摘除術を行っ た stage II と stage IIIA の再発率はほぼ同程度の頻度（30\%）であった。

到達経路に関して stage III 以上の症例で単純腎摘除術を施行した全例が経腰式・経腹膜外経路で行わ れ非治癒切除例であったのに対して根治的腎摘除術を行った症例は経腹式または経胸腹式経路であり， 後腹膜リンパ節郭清術, 下大静脈腫瘍血栓除去術あるいは隣接葴器の合併切除など払大手術が可能で あった。

特に stage IIIA の症例において stage I, II の各症例との生存率に関する比較では有意差がなく, 再発 率も stage II と同様の頻度であり腫瘍塞栓除去術を完璧に行らことが重要であると考えた.

以上の結果から, 腎細胞癌の手術の際に良好な予後を期待できる条件は PS が 0 であること, stage 別 で stage I IIIA までは根治的腎摘除術を行うこと, stage IIIB 以上でも治瘾切除が可能である限り, 経 腹式あるいは経胸腹式経路で根治的腎摘除術を含む腫瘍の合併切除を積極的に行うことが予後の改善に つながるものと確信した.

キーワード : 腎細胞癌, 根治的腎摘除術, 単純腎摘除術, リンパ節郭清

\section{緒 言}

腎細胞癌は手術療法以外に根治性を期待できる方法 がないため腫瘍を完全に摘出することが治療法の基本 である。
従って，腫瘍が原発巣に限局している場合は腎摘除 術が行われる，進行癌でも孤立性転移を有する症例に 対しては腎摘除術に加兄, 積極的に転移巣の切除を行 らことにより治瘜を認める場合もあること文2, また多 
発性転移を有する症例でも腎摘除術後に延命効果ある いは転移巣の消裉を認める場合があること年4)，さらに 腎摘除術後にインターフェロンの有効率が高(、5)6)な どの理由から腎摘除術が盛んに行われている。

手術療法は予後を左右する治療側の因子として宿主 側, 腫瘍側とともに重要な役割を果たしているものと 考学られる7).

そこで原発巣摘除術を行った腎細胞癌148例を対象 として手術療法が予後に及ぼす影響について performance status (PS), 性別, stage, 腎摘除術式, リン パ節郭清の有無掞よび腎摘出重量に分けて統計学的検 討を行ったので文献的考察を含めて報告する.

\section{対象および方法}

対象は 1961 年 9 月から1989年 8 月までの 29 年間に群 馬大学泌尿器科で入院治療した170例のうち腎摘除術 を行った148例である.

性別は男性101例, 女性47例であり, 平均年齢は58歳 であった。患側は 2 例の両側腎細胞癌を含むため右側 74, 左側76の計150腎であった。

腎摘除術式に怙いて根治的腎摘除術とは切開法, 到 達経路, リンパ節郭清の有無を問わず腎動脈, 腎静脈 の順に腎茎血管を処理した後, Gerota 筋膜を開かず副 腎と一緒に原発巣摘除を行ったものであり，それ以外 の腎摘除術を行った症例は全て単純腎摘除術として取 り扱った。

リンパ節郭清は局所リンパ節郭清を行った症例を郭 清施行例とした，局所リンパ節とは，患側により右側 は患側腎茎部, 下大静脈右, 大動静脈間リンパ節の範 囲を，左側は患側腎茎部，旁大静脈左，大動静脈間り ンパ節の範囲を各々郭清したものと規定した。

抎大手術（Extended operation）として下大静脈腫 瘍血栓除去を行った症例の全例に根治的腎摘除術が施 行されているが，それらは全て対象症例として取り 扱った。

症例は1961年から1978年までは主に単純腎摘除術 が，1979年以後は根治的腎摘除術が施行されるように なった。また，リンパ節郭清術も1985年以後，ほぼ全 例に併用されている。

術後治療はインターフェロン単独あるいはインター フェロンとUFT の併用療法的が主に施行された。

進展度は Robson の分類に従い，予後の算出は日本 癌治療学会生存率算出規約に基づき Kaplan-Meier 法 を用い，生存率の比較は Generalized Wilcoxon Test, Cox-Mantel Test 及び Logrank Test を用いた。起算
日は手術日とし，1989年 8 月31日までの成績とした。

$$
\text { 結 果 }
$$

1. 症例の年齢, 性別特徵（Table 1)

症例数は男性 101 例，女性47例で，男女比は2.1：1 と男性が多かった。平均年龄は，58歳で男性57.6歳, 女性58.8歳であり，女性にやや高齢の傾向を認めた。

2. 腫瘍の患側・局在での分類 (Table 2)

患側は右側74, 左側76の合計150腎であり，腫瘍の局 在は左右ともに腎下極に若干多かったが，統計学的有 意差はとくに認められなかった。

3. PS と stage での比較 (Table 3)

PS が 1 以下の症例は 141 例で全体の $95 \%$ 占めて いたが，PS が 4 の症例は 1 例もなかった。

Stage 分類では stage I の症例が71例で全体の $48 \%$ であり, stage IV も30例で全体の $20 \%$ を占めていた。 また, PS は Stage IV の症例で高い傾向であった。

4. 手術術式の検討 (Table 4)

術式は148例中，根治的腎摘除術 100 例，単純腎摘除 術46例, 腎部分切除術 1 例及び腎腫瘍核出術 1 例で あった。

根治的腎摘除術は初期には腹部正中切開又は旁腹直

Table 1 症例の年齢, 性別, 特徵

\begin{tabular}{lclc}
\hline & \multicolumn{1}{c}{ 男 } & \multicolumn{1}{c}{ 女 } & 総数 \\
\hline 症 例 数 & 101 & 47 & 148 \\
平均年柃 & 57.6 & 58.8 & 58.0 \\
年齢篹囲 & $30 \sim 85$ & $34 \sim 87$ & $30 \sim 87$ \\
男女 比 & 2.1 & 1 & \\
\hline
\end{tabular}

Table 2 腫場の患側，局在による分類（148例）

\begin{tabular}{|c|c|c|c|c|c|}
\hline 患側 & $\begin{array}{l}\text { 局在 } \\
\text { 上糧 }\end{array}$ & 中央 & 下極 & 全体 & 計 \\
\hline 右 & 28 & 12 & 32 & 2 & 74 \\
\hline 左 & 23 & 13 & 35 & 5 & 76 \\
\hline 竐 & 51 & 25 & 67 & 7 & 150 \\
\hline
\end{tabular}

Table 3 Staging と PS の比較（148例）

\begin{tabular}{c|rrrrrr}
\hline & \multicolumn{7}{|c}{ PS } \\
Stage & 0 & 1 & 2 & 3 & 4 & 計 \\
\hline I & 61 & 8 & 2 & 0 & 0 & 71 \\
II & 29 & 2 & 0 & 0 & 0 & 31 \\
III & 15 & 1 & 0 & 0 & 0 & 16 \\
IV & 18 & 7 & 3 & 2 & 0 & 30 \\
\hline 訫 & 123 & 18 & 5 & 2 & 0 & 148
\end{tabular}


Table 4 手術術式 (148例)

\begin{tabular}{|c|c|c|c|c|c|}
\hline 霓墒除術 & & 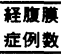 & 絓的腹膡 & 経福膡外 & 緇 数 \\
\hline 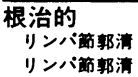 & 有 & $\begin{array}{l}97 \\
53 \\
44\end{array}$ & $\begin{array}{l}3 \\
0 \\
3\end{array}$ & $\begin{array}{l}0 \\
0 \\
0\end{array}$ & $\begin{array}{r}100 \\
53 \\
47\end{array}$ \\
\hline $\begin{array}{l}\text { 単純 } \\
\text { リンバ笛垶清 } \\
\text { リンバ䇫部清 }\end{array}$ & $\begin{array}{l}\text { 有 } \\
\text { 無 }\end{array}$ & $\begin{array}{l}2 \\
0 \\
2\end{array}$ & $\begin{array}{l}0 \\
0 \\
0\end{array}$ & $\begin{array}{c}44 \\
0 \\
44\end{array}$ & $\begin{array}{r}46 \\
0 \\
46\end{array}$ \\
\hline 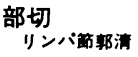 & 無 & $\begin{array}{l}1 \\
1\end{array}$ & $\begin{array}{l}0 \\
0\end{array}$ & $\begin{array}{l}0 \\
0\end{array}$ & 1 \\
\hline $\begin{array}{l}\text { 核出 } \\
\text { リンハ笽部清 }\end{array}$ & 無 & $\begin{array}{l}0 \\
0\end{array}$ & $\begin{array}{l}0 \\
0\end{array}$ & $\begin{array}{l}1 \\
1\end{array}$ & $\begin{array}{l}1 \\
1\end{array}$ \\
\hline 総数 & & 100 & 3 & 45 & 148 \\
\hline
\end{tabular}

Table 5 再発症例に拈ける stage 別検討

\begin{tabular}{|c|c|c|c|c|c|c|c|}
\hline Robson & 術式 & & リンバ & 非治击 & 不明 & 再 器 & 平均锤案期間 \\
\hline Stage & & & 茅部清 & 切除 & & (\%) & 平均十標準竞差 (ヶ月) \\
\hline \multirow[t]{4}{*}{ I } & & 71 & & & & & \\
\hline & 根治的 & 46 & 25 & 0 & 0 & $4 / 46(8.7)$ & $33.5 \pm 7.0$ \\
\hline & 临 純 & 24 & 0 & 0 & 1 & $9 / 23(39.1)$ & $99.1 \pm 16.2$ \\
\hline & 部 切 & 1 & 0 & 0 & 0 & 0 & \\
\hline \multirow[t]{3}{*}{ II } & & 31 & & & & & \\
\hline & 根治的 & 23 & 14 & 0 & 2 & $6 / 21(28.6)$ & $39.9 \pm 9.5$ \\
\hline & 単 純 & 8 & 0 & 0 & 0 & $5 / 8(62.5)$ & $51.3 \pm 20.2$ \\
\hline III & & 16 & & & & & \\
\hline \multirow[t]{2}{*}{ A } & 根治的 & 11 & 6 & 1 & 0 & $3 / 10(30.0)$ & $31.0 \pm 8.4$ \\
\hline & 単 純 & 0 & 0 & 0 & 0 & & \\
\hline \multirow[t]{2}{*}{ B } & 根治的 & 0 & 0 & 0 & 0 & & \\
\hline & 単 純 & 2 & 0 & 2 & 0 & & \\
\hline \multirow[t]{2}{*}{ c } & 根治的 & 2 & 1 & 1 & 0 & $0 / 1(0.0)$ & \\
\hline & 単 純 & 1 & 0 & 1 & 0 & & \\
\hline N & & 30 & & & & & \\
\hline \multirow[t]{2}{*}{ A } & 根治的 & 2 & 0 & 0 & 0 & $2 / 2(100.0)$ & \\
\hline & 単 純 & 1 & 0 & 1 & 0 & & \\
\hline \multirow[t]{3}{*}{ B } & 根治的 & 16 & 7 & 15 & 0 & $0 / 1(0.0)$ & \\
\hline & 单 純 & 10 & 0 & 10 & 0 & & \\
\hline & 核 出 & 1 & 0 & 1 & 0 & & \\
\hline
\end{tabular}

筋切開法, 最近では肋骨弓下全横切開法 (Chevron incision)による経腹式手術が97例に行われ，3 例には 旁腹直筋切開法に第 $9 ， 10 ， 11$ 肋骨切除を併用した経 胸腹式手術が行われた。

単純腎摘除術は腹部正中切開法からの経腹式手術を 行った 2 例を除いて，44例が経腰式，経腹膜外手術が 行われた。

リンパ節郭清は根治的腎摘除術が行われた 100 例中 の53例に施行されたが，それらは全て腎摘除後に行わ れた。

5. 再発例の検討 (Table 5)

症例を stage 別かつ手術術式により分類し, 再発の 有無について検討を行った。

根治的腎摘除術は単純腎摘除術に比べて stage I 〜II では再発率は低く，また両者はともに stage I に
比較して stage II の再発率は高かった。ささらに根治的 腎摘除術症例で, stage II と stage IIIA の再発率は前 者が $28.6 \%$, 後者が30\%とほぼ同一頻度であった。 stage IIIB〜IVB までの進行癌で単純腎摘除術を行っ た全例が非治癒切除例であった。根治的腎摘除術を 行った症例は stage IVAの 2 例と stage IVB の16例 中の 1 例が治癒切除術であった. stage IVAの 2 例は 各々, 脾蔵への浸潤のため脾摘除術を, また結腸浸潤 のため結腸合併切除術を行ったが遠隔転移のためとも に 1 年以内に癌死した. stage IVB の 1 例は根治的腎 摘除術に耳下腺転移巣摘出術を行ったが術後 3 年で再 発なく生存している。

6. 生存率の比較検討

性別，PS，腎摘除術式，リンパ節郭清の有無，腎摘 出重量及び stage により分類を行い, 生存率に関して 統計学的に比較検討した.

1）性別による比較（Table 1)

男女別の比較ではとくに有意差は認められなかっ た.

Fig. 1 Kaplan-Meier 法による生存率

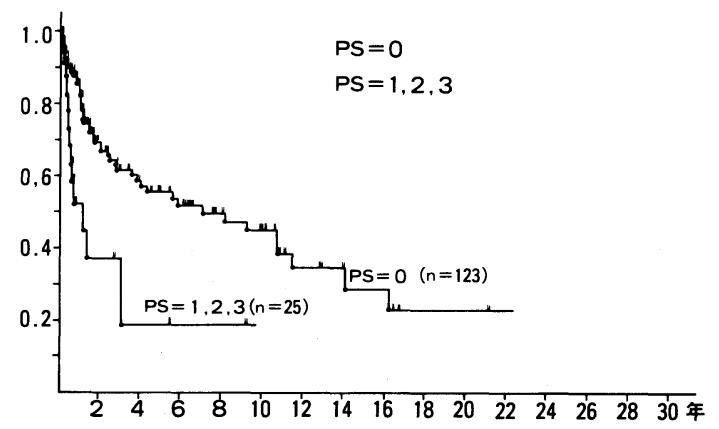

Fig. 2a Kaplan-Meier 法による生存率

NEPHRECTOMY CASES IN RENAL CELL CARCINOMA $(n=148)$

STAGE I

STAGE I

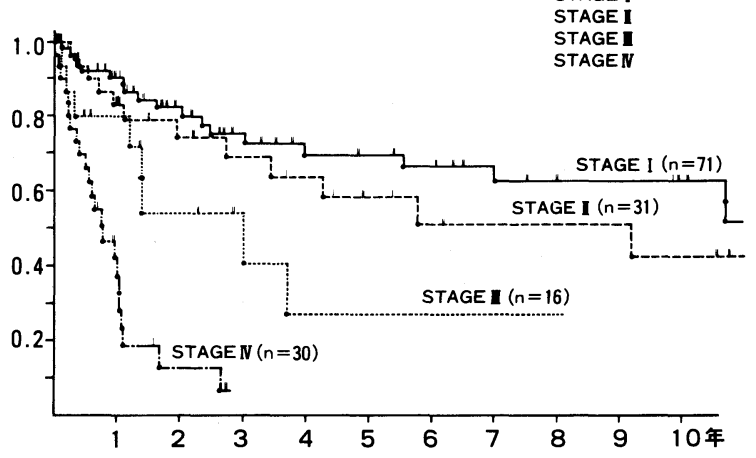


Fig. 2b Kaplan-Meier 法による生存率

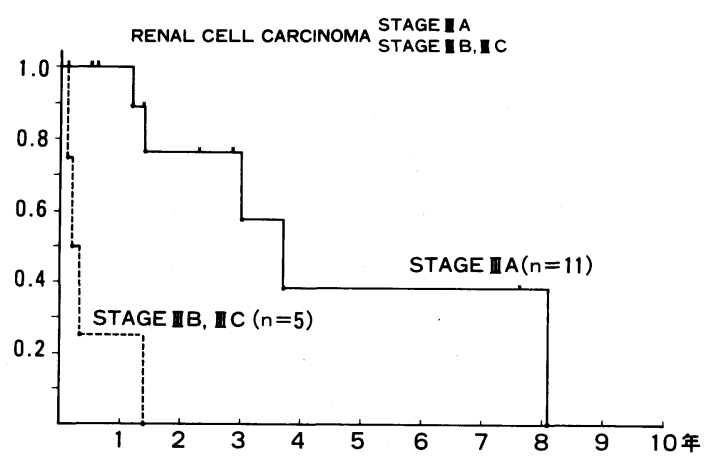

Fig. 3 Kaplan-Meier 法による生存率 RENAL CELL CARCINOMA STAGE I,I RADICAL
STAGE I,I SIMPLE

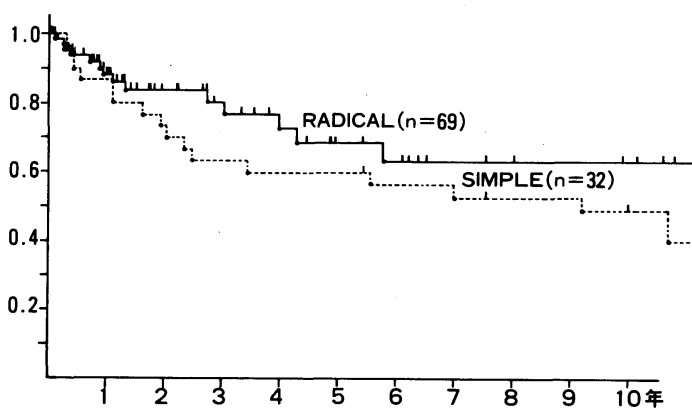

2) PSによる比較 (Fig. 1).

PS が 0 と PS が 1 以上の症例で比較したところ前 者で有意に生存率は良かった（ $\mathrm{p} \leqq 0.01 ）$.

3） stage 分類による比較（Fig. 2a，2b)

stage I 又はII と stage IV との比較では前者が有意 に生存率は高く（ $\mathrm{p} \leqq 0.01 ）$, stage III と stage IV で も前者が有意に高いといら結果であった $(0.01<\mathrm{p} \leqq$ 0.05)。また stage I 又はII と stage IIIA との比較で は, 特に有意差を認めず, stage IIIA と stage IIIB+ $\mathrm{C}$ との比較では, 前者に有意に高い生存率を得た $(\mathrm{p} \leqq$ 0.01 ).

4）腎摘除術式による比較（Fig. 3）

単純腎摘除術式と根治的腎摘除術において stage I 〜IV での全症例での比較では特に有意差は認めな かったが, stage I〜II までの症例での比較では後者が 有意に生存率は良かった（ $\mathrm{p} \leqq 0.01 ）$.

5）リンパ節郭清の有無による比較（Fig. 4）

全症例における検討で特に有意差を認めず，また stage I II までの low stage 症例の検討でも特に有意
Fig. 4 Kaplan-Meier 法による生存率 RENAL CELL CARCINOMA STAGE I, I LYMPHADENECTOMY(+) STAGE I, I LYMPHADENECTOMY(-)

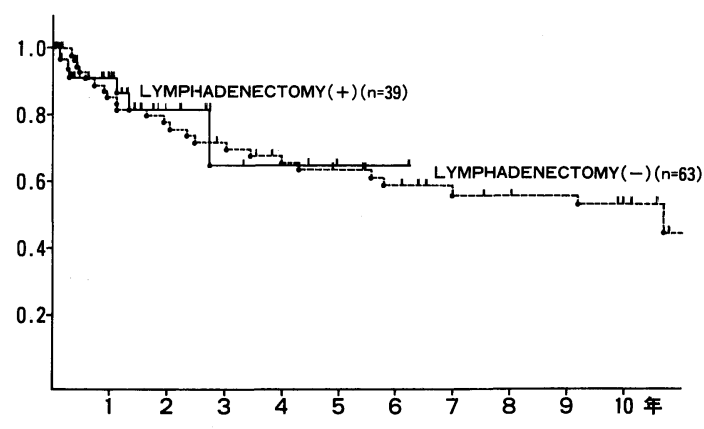

Fig. 5 Kaplan-Meier 法による生存率

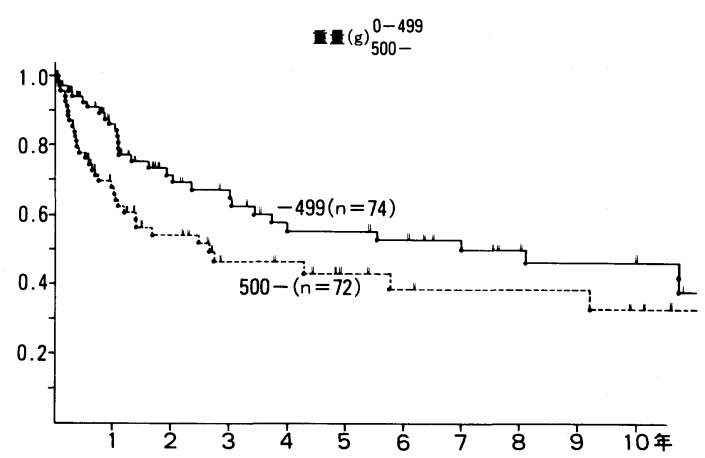

差はなく，現在のところ予防的郭清の意義は認めてい ない。

6）腎摘出重量（Fig. 5)

腎摘除術を施行した 146 例について $500 \mathrm{~g}$ 未満と $500 \mathrm{~g}$ 以上に分けて生存率の比較を行ったところ前者が有意

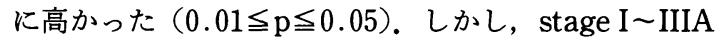
までの123例の検討では特に有意差は認めなかった。

\section{考 察}

手術療法は腎細胞癌の治療として根治性を期待でき る唯一の方法であるため, 予後を規定する治療側因子 として重要である。

手術治療に対する予後関連因子は多数あり，それら が相互に複雑に関係していると考えられる。そのため 予後について一概に評価することはできないが，手術 適用の際に予後をあらかじめ推測しておくことは重要 である。

今回は，その見地から予後規定因子と考えられる患 者の PS (performance status)。性別，stage，手術術 式, リンパ節郭清の有無及び腎摘出重量を選んで検討 し，今後の治療方針に若干の知見を得た。 
手術療法は機能保存を目的とした腎腫瘍核出術や腎 部分切除術など特殊な場合を除いて腎摘除術が治療の 主体であり単純腎摘除術と根治的腎摘除術の 2 つの術 式がある。

Chute $^{8)}$, Robson $^{9)}$ 及び Middleton ${ }^{10)} ら か ゙$ 根治的腎摘 除術の優秀性を報告して以来, 本術式が単純腎摘除術 に代わるものとして広く用いられている。

根治的腎摘除術 ${ }^{11) 12)}$ は最初に腎茥部の腎動静脈を処 理した後に Gerota 筋膜を開くことなく周辺の脂肪織 とともに en bloc に腎を摘出するといら術式である. 理論的には, 腫瘍を manipulationする前に腎血管の 処理を行い, Gerota 内の脂肪織も残すことがないた め, 利点として，1）局所再発又は遠隔転移を生ずるこ とがない.2）単純腎摘除術では根治不可能な下大静脈 腫場血栓除去術, リンパ節郭清術または隣接臓器合併 切除などの拡大手術が可能である.3）遠隔転移が孤立 性で完全切除が可能である場合，根治性が期待できる などが挙げられる。

しかし，最近では里見ら ${ }^{13)}$ が経腹式根治的腎摘除術 と経腰式単純腎摘除術では予後に関して有意差はな かったと報告しているように根治的腎摘除術の有用性 を疑問視する論文も散見されるため，術式に関する prospective study が要求されるが, 各術式の特徵を考 慮せず漫然と studyを行った場合にはたと結果を得 るにしても nonsense な trial となる可能性がある，自 験例の手術術式の結果に基づいて，その点について， stage 別に若干の考察を行ってみた.

stage I〜II までの症例を対象とした場合，予後に関 して根治的腎摘除術は単純腎摘除術に比べ有意差を もって良好であり，また平均観察期間は異なるため明 確なことは言及できないが，再発率においても前者は 後者に比べて低い傾向であった。根治的腎摘除術を 行った症例におけるリンパ節郭清併用群と非併用群と の比較では特に有意差を認めなかった ${ }^{14) 15)}$. しかし,リ ンパ節郭清後にリンパ節転移陽性を認めた症例もあっ たため, staging operationの意味からも stage I ～II の症例に対しては，根治的腎摘除術にリンパ節郭清を

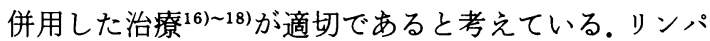
節郭清の範囲は, 最近の 4 年間でリンパ節郭清を行っ た100例以上の症例の経験で, low stage 症例でのリン パ節転移陽性例は少ないため所属リンパ節の全郭清は 行わず，現在では患側腎茎，大動静脈間リンパ節を含 む患側域の郭清だけを行っている。

Robson 分類では, stage I と II を規約に従って正確
に分けることは非常に困難である。すなわち，腫瘍の 全体を肉眼的かつ病理組織学的に検索することは不可 能に近いため stage II に対して false negative の症例 が stage IV含まれている可能性がある．従って今回 は stage I II でまとめて, 腎摘除術式とリンパ節郭清 術の有無について検討を行った。仮に stage I と IIが 正確に診断されるとしたら，腎被膜内に限局している stage Iでの手術術式に関する prospective randomized trial が手術の侵襲性及び根治性という点から有 用となる可能性はあるかも知れない。

stage III では stage IIIA と stage IIIB+Cに分けて 検討したところ, stage IIIA では生存率において stage I, II と有意差がなく, 再発率も stage II と変ら なかったが, stage IIIA と stage IIIB $+\mathrm{C}$ の生存率に おける比較では前者が有意に良好であった。また単純 腎摘除術を行った症例は全て非治瘾切除となっている ことから, stage III でも根治的腎摘除術にリンパ節郭 清を併用すべきと考学る。特に stage IIIA では下大静 脈腫煌血栓除去術の成否が予後を決定するといえる。 stage IVA は, 合併切除が可能であれば当然, 根治的 腎摘除術が選ばれる. stage IVB では遠隔転移例であ り，腎摘除術の適否に関しては賛否両論があり，まだ 結論がでていない状態である。 Johnson ら ${ }^{19220)}$ は転移 性腎細胞癌に対する腎摘除術の役割として,1）局所症 状の軽減 (血尿, 疼痛, 発熱, neoplastic syndrome な ぞ)，2）腫瘍の播種を防ぐための reduction surgery, 3）転移巣の消褪を期待した延命効果，4）Tumor reduction surgeryによるホルモン療法や薬物療法の 増強効果, 5) 原発巣摘除による患者の精神的負担の軽 減が目的であるが，腎摘除術は多発性転移巣に対して は適用がなく，孤立性転移を有する場合に限って延命 効果が期待されるかも知れないと報告している。転移 性腎癌の孤立性転移巣に対する外科的アプローチは, Burney $ら^{21)}$ が1939年, 孤立性肺転移巣に対して肺葉 切除術後, 23 年間の長期生存例を報告したのが最初で ある。また Middleton ら ${ }^{22)}$ は腎細胞癌の孤立性転移を 有する自験例 8 例を加えた51例の集計から，孤立性転 移巣切除例の 3 年及び 5 年生存率は各々， $45 \%, 34 \%$ であり，転移のない症例の生存率に匹敵すると報告し た。その後も，転移部位や転移巣の切除時間などの面 から予後を検討した報告 231 27)が認められるが, 完全治 癒は難しく，当初期待していたほどの延命効果は期待 できないと考えられている。しかし，腎細胞癌は外科 治療以外に根治的手段を持たず，また転移巣を完全切 
除できた症例の一部に長期生存が認められることか ら，現状では手術により完全治癒が見込まれ，延命効 果が期待できる症例に限って根治的腎摘除術を施行す べきかもしれない.逆に，根治性を期待できず Johnson らの定義に当てはまる症例に対しては単純腎摘除術の 適応が妥当であると考学る。

すなわち， stage IV においては完全治癒を期待でき る症例は根治的腎摘除術を，また， palliativeな治療を 目的とする症例に対しては単純腎摘除術とを選択する といらことになる。

すなわち，各 stage 毎に用途に応じた術式を選択す る場合，根治的腎摘除術の適用は意外に広いことが分 かる。

しかし, 単純腎摘除術も遠隔転移を有する症例の palliative operation としてばかりでなく，侵襲性が低 い術式であるという理由から高龄者や合併症を有する 症例や腹腔内手術の既応があり経腹的アプローチでは 摘出困難と予想される症例などに対して適応があり， 捨て難い術式であると考える。

以上，手術術式を中心に考察を行ってきたが，最後 に腎摘出重量と予後との関係について述べてみたい。 摘出重量が重いほど予後が悪いといら報告7)が多い。 自験例では全症例に括いて $500 \mathrm{~g}$ 前後で症例を分けて 予後を検討したところ $500 \mathrm{~g}$ 未満のものに予後が有意 に良いといら結果であったが, stage I〜IIIA までの症 例の検討では有意差はなかったことから腎摘出重量が 重いほど，すなわち腫怚重量があるものほど予後は悪 く，また high stage となる傾向があるように思われ た.

従って術前画像診断にて腫瘍の大きさをあらかじめ 計測しておく事は重要である ${ }^{29)}$. low stage の症例に 対して重量が予後因子になり得るかは今後の課題とし たい.

\section{結語}

群馬大学泌尿器科で手術療法を行った148例を対象 として手術に打ける予後因子と考えた。性別，PS， stage, 腎摘除術式, リンパ節郭清の有無及び腎摘出重 量をとり上げ, 統計学的に予後に関する検討を行った。

性別は予後に関係せず，PS は正常の場合に有意に 生存率は高かった. stage 別では各 stage I, II, III の 間では生存率に有意差はなく, stage IIIA と IIIB $+\mathrm{C}$ またはIVの比較では，前者が有意に良かった。腎摘出 重量は, $500 \mathrm{~g}$ 前後で比較したところ全症例を対象とし た場合， $500 \mathrm{~g}$ 以下で有意に生存率が高かった。術式で
は, stage I 〜II までの根治的腎摘除術と単純腎摘除術 を行った症例では前者が有意に生存率が高かったが,

リンパ節郭清では施行，未施行の症例間で有意差は認 めなかった。

各 stage 別に根治的腎摘除術と単純腎摘除術の適応 に関して自験例を用いて検討を行ったところ，prospective study を行う意義のあるものは術前に stage が正確に診断される場合, stage I に適応する価値があ るように思われた。

\section{文献}

1) Middleton,R.G.: Surgery for metastatic renal cell carcinoma. J. Urol., 97, 973, 1967.

2）西尾恭規, 西村一男, 飛田収一, 岡田裕作, 竹内秀 雄, 宮川美栄子, 岡田謙一郎, 吉田 修: 腎細胞癌 に対する根治的腎摘除術の治療成績. 第 1 報。腎癌 取扱い規約による進展度分類と予後。泌尿紀要, 33, 337-343, 1987.

3) Maldazys, J.D. and de kerninon. J.B. : Prognostic factors in metastatic renal carcinoma. J. Urol., 136, 376-379, 1986.

4) Freed, S.F., Halperin, J.P. and Gordon, M.: Idiopatic regression of metastases from renal cell carcinoma. J. Urol., 118, 538-542, 1977.

5) De Kernion, J.B., Gregory Sarna., Figlin, R.A., Lindner Arle. and Smith, R.B.: The treatment of cell carcinoma with human leukocyte alphainterferon. J. Urol., 130, 1063-1065, 1983.

6）小林幹男, 今井強一, 山中英寿：堅細胞癌に対する インターフェロン $\alpha$ と UFT（またはFT-207）の 併用療法。日癌治, 24(7)，1437-1446, 1989.

7）阿曾佳郎, 田島 郭：腎癌の治療成績とそれを左 右する因子一特に尿路外症状との関連について 一. 癌の臨床, 27, 867-876, 1981,

8) Chute, R., Soutter, L. and Kern, W.S., Jr.: Value of thoraco-abdominal incinion in removal of kidney tumors. New Engl. J. Med., 241, 951, 1949.

9) Robson, C.J., Churchill, B.M. and Anderson, W. : The results of radical nephrectomy for renal cell carcinoma. J. Urol., 101, 297-301, 1969.

10) Middleton, R.G.: Radical thoracoabdominal nephrectomy for renal cell carcinoma. J. Urol., 110, 36-37, 1973.

11) Skinner, D.G., Colvin, R.B., Vermillion, C.D., Pfister, R.C. and Leadbetter, W.F.: Diagnosis and management of renal cell Carcinoma. Cancer., 28, 1165-1177, 1971.

12）岡本重禮：根治的腎摘除術術. 臨泌, 36, 113-120, 1982. 
13）里見佳昭, 仙賀 裕, 福田百邦, 中橋 満, 穂坂正 彦, 近藤猪一郎, 吉邑貞夫, 福島修司, 古烟哲彦, 塩崎 洋, 石塚栄一, 福岡 洋: 腎癌333例の臨床 統計的観察. 第 3 報。手術, 手術所見及び手術成績. 日泌尿会誌，78，1394-1402，1987.

14) Dekernion, J.B. : Lymphadenectomy for renal cell carcinoma. Therapeutic implication. Urol Clinics of Noth Areri., 7, 679-703, 1980.

15) Chatelain, C.: Should Lymphadenectomy be associated to radical nephreatomy in renal cell carcinoma?. Renal Tumors : Proceedings of the First International Symposium on Kidney Tumors, 493-495, 1982.

16) Herrlinger, A., Schrott, K.M., Sigel, A. and Giedl, J.: Result of 381 transabdominal radical nephrectomies for renal cell carcinoma with partial and complete en bloc lymphmode dissection. World. J. Urol., 2, 114-121, 1984.

17）增田富士男, 吉田正林, 近藤直弥, 高橋知宏, 近藤 泉, 吉田 希: 腎細胞癌の治療におけるリンパ節 郭清の評価。癌の臨床, 31，1889-1893， 1985.

18）山内民男，寿美周平，石橋克夫，鷲塚 誠，国保昌 紀, 河合恒雄：腎癌の根治的腎摘術における後腹 膜リンパ節郭清術の意義について。 日泌尿会誌, 78, 2114-2121, 1987.

19) Johnson, D.E., Kaesier, K.E. and Samuel, M.L. : Is nephrectory justified in patients with metastatic renal carcinoma?. J. Urol., 114, 27-29, 1975.

20) Johnson, D.E. and Swanson, D.A : The role of nephrectomy in metastaticc renal carcinoma. Cancer of the Genitourinary Tract Raven Press, New York, 27-32, 2979.

21) Barney, J.D. and Churchill, E.J.: Adenocar- cinoma of the kidney with metatasis to the lung: cured by nephrectmy and lobectomy. J. Urol., 42, 298, 1939.

22) Middleton, R.G. : Surgery for metastatic renal cell carcinoma. J. Urol., 97, 973, 1967.

23) Skinner, D.G., Colvin, R.B., Vermillion, C.D., Pfister, R.C. and Leadbetter, W.F.: Diagnosis and management of remnal cell carcinoma. A clinical and pathologic study of 309 cases. Cancer, 28, 1165, 1971.

24) Tolia, B.M. and Whitmore, W.F., Jr.: Solitary metastasis from renal cell carcinoma. J. Urol., 114, 836, 1975.

25) Michael, J.O., Horst, Z., David, C.U., and Philip, E.B.: The treatment of renal cell carcinoma with solitary metastasis. J. Urol., 120, 540-542, 1978.

26) De Kernion, J.B., Ramming, K.P. and Smith, R. B.: The natural history of metastatic renal cell carcinoma : a computer analysis. J. Urol, 120, 148, 1978.

27) Boxer, R.J., Waisman, J., Lieber, M.M., Mampaso, F.M. and Skinner, D.G. : Renal carcinoma : Computer analysis of 96 patients treated by nephrectomy, J. Urol, 122, 598-601, 1979.

28) Mertin, K.D., Raymond, D.P., Lawrence, J. E. and Robert, P.H.: Results of surgical treatment of renal cell carcinoma with solitary metastasis. J. Urol, 140, 277-279, 1988.

29）大西哲郎, 町田豊平, 増田富士男, 飯塚典男, 中内 憲二, 河原 元, 白川 浩; 腎細胞癌の腫瘍径が有 する臨床的意義に関する検討. 日泌尿会誌, 81 , 569-575, 1990.

（1990年 9 月 18 日受理） 